\title{
Utilizing American and Korean College Admissions Exams to Assess Adult ESL Students' College Readiness
}

\section{Adam Weiss ${ }^{1}$ Sang Hwang ${ }^{2}$}

Assistant Professor of Education, West Texas A\&M University, USA.

Email:aweiss@,wtamu.eduTel:(806)651-2616

'Professor of Education, West Texas AङM University, USA.

Email:shwang@wtamu.eduTel:(806)651-2617

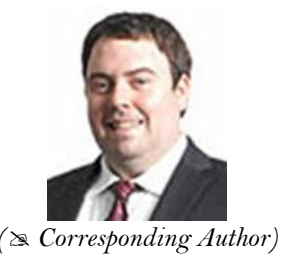

Abstract

While colleges in the United States often use standardized tests such as the ACT and SAT to measure students' college readiness, students' performance on other international assessments could also provide educators with useful data. Korean universities have utilized the English portion of the Korean College Scholastic Ability Test (CSAT) to measure Korean students' English language proficiency for decades (Kim et al., 2012; Lee and Winke, 2013; Bae and Lee, 2018). As the majority of Korean students are English Language Learners (ELLs) (Lee, 2014) ELL students participating in English as a Second Language Programs in the United States might also benefit from taking the exam. The present study utilized the Korean College Scholastic Ability Test (CSAT), the ACT English Test, and the ACT Reading Test to evaluate ELL students' college readiness in the areas of English reading comprehension and English writing conventions and style. Researchers administered the exams to international students who had participated in a semester-long, English as a Second Language (ESL) program at a regional university in the Southwestern United States. The study investigated participants' perceptions of their experiences taking each exam. Results from student surveys indicated that students viewed the CSAT as a beneficial English assessment and would recommend the exam to other ESL students. Students' performance on the CSAT proved relatively similar to their performance on the ACT reading and English exams. As such, the CSAT could prove a valuable assessment tool for ESL educators in the United States and across the globe.

Keywords: College readiness, Standardized tests, Korean College scholastic ability test, ESL programs, Adult English language learners, Assessment.

Citation | Adam Weiss; Sang Hwang (2019). Utilizing American and Korean College Admissions Exams to Assess Adult ESL Students' College Readiness. Asian Journal of Social Sciences and Management Studies, 6(2): 30-38.

\section{History:}

Received: 16 July 2019

Revised: 19 September 2019

Accepted: 22 October 2019

Published: 9 December 2019

Licensed: This work is licensed under a Creative Commons

Attribution 3.0 License $(\mathrm{cos})$ Er

Publisher: Asian Online Journal Publishing Group
Acknowledgement: Both authors contributed to the conception and design of the study.

Funding: This study received no specific financial support

Competing Interests: The authors declare that they have no conflict of interests.

Transparency: The authors confirm that the manuscript is an honest, accurate, and transparent account of the study was reported; that no vital features of the study have been omitted; and that any discrepancies from the study as planned have been explained.

Ethical: This study follows all ethical practices during writing.

\section{Contents}

1. Introduction 31

2. Literature Review ........... 31

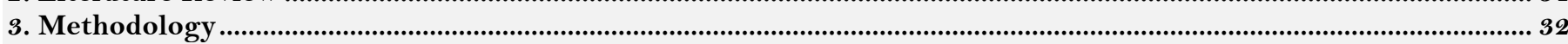

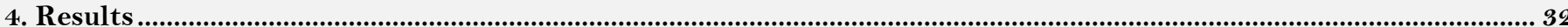

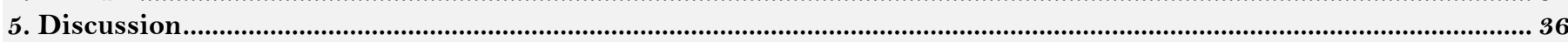

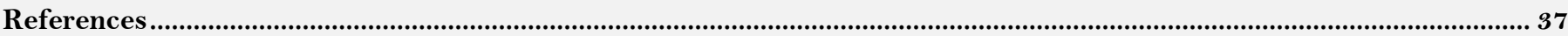




\section{Contribution of this paper to the literature}

The present study contributes to the existing literature by utilizing the Korean College Scholastic Ability Test (CSAT), the ACT English Test, and the ACT Reading Test to evaluate ELL students' college readiness in the areas of English reading comprehension and English writing conventions and style.

\section{Introduction}

Since the passage of the Immigration and Nationality Act of 1965, which outlawed immigration quotas on specific countries of origin and allowed for family reunification, the United States has become increasingly diverse. Approximately fifty years after the passage of the law, the percentage of people living in the U.S. who were born in another country has tripled (Gjelten, 2015). As a result, the number of English Language Learners (ELLs), or English as a Second Language (ESL) Learners, in U.S. K-12 schools, colleges, and universities has grown significantly. In fact, since the year 2000, the number of ELL students in K-12 schools has increased by 1 million, and the percentage of ELL students in U.S. K-12 schools has grown from $8.1 \%$ to approximately $10 \%$ of the entire student population (Bergey et al., 2018; National Center for Education Statistics, 2019). The percentage of ELL students in colleges and universities has also risen. International students form one significant group of higher education students who are English Language Learners (Bergey et al., 2018). Since 1965, the number of international students in U.S. institutions has more than quadrupled to 1.1 million students (Bergey et al., 2018; Zong and Batalova, 2018). Moreover, nearly $24 \%$ of community college students and $20 \%$ of college students in the United States have parents who were born outside of the U.S. (Bergey et al., 2018). While not all international students and first-generation Americans are ELLs, many of whom are. As a result, American schools and institutes of higher education have needed to expand their language supplemental instruction programs, including English as a Second Language programs (Bergey et al., 2018). As enrollments of ELLs in American schools and colleges have increased, so has the need to evaluate whether ELLs pursuing higher education possess the college readiness and English language skills to be academically successful. Moreover, educators in adult ESL classrooms must find standardized assessments to administer in the classroom to evaluate students' English listening and reading abilities along with students' knowledge of English grammar conventions (Chalhoub-Deville and Turner, 2000).

While the number of international students in the United States had steadily increased from 1965-2016, since the 2017-2018 academic year, the number of international students has declined for two years in a row. This decrease in international student population coincides with increased anti-immigrant political rhetoric within conservative political factions in the United States and the passage of President Trump's "Buy American and Hire American" executive order in 2017 (Redden, 2018; Know, 2019). With the noticeable decrease in international students, U.S. institutes of higher education have experienced financial and social impacts on campus. For example, many university professors and staff describe the presence of foreign students as a positive asset to universities because the presence of international students increases American-born students' multicultural awareness and cultural understanding (Foote et al., 2015). Therefore, a decline in international students could lead to a decline in students' overall cultural competence. Furthermore, some colleges and universities, many of whom have academic programs that depend on the revenue earned from the elevated tuition rates international students pay, now face financial challenges (Leiber, 2019).

This trend particularly affected the university that was the setting of the present study. The number of students enrolled in the semester-long, ESL college-bridge program had declined from a high of approximately 100 students at the start of the decade to nine students in fall 2018. Indeed, the fall 2018 semester was the terminal semester of the program; the program shut its doors a month after the study had concluded.

The present study intended to investigate adult ESL students' college readiness and their perception about their English proficiency using three free, publicly available, standardized achievement tests. All three tests are paper-based tests that do not require trained graders to score and evaluate the test results. The three tests, the Korean College Scholastic Ability Test (CSAT) and the official practice tests of the ACT English and Reading Tests, were chosen to simulate quick, formative assessments that an adult ESL educator could administer to assess students' English language abilities and college readiness. In this particular study, the tests measured students' knowledge of English reading comprehension and English writing conventions and style. Researchers conducted the present study at a regional, public university in the Southwest region of the United States, and the study population included international students participating in a semester-long, ESL college-bridge program. Students had attended the semester long, intensive English program so that upon successful completion of the program, students would be eligible to take undergraduate and graduate level, credit-bearing courses without having to meet a minimum score criteria on a standardized test of English proficiency such as the TOEFL, IELTS, or PTE.

Researchers administered the CSAT to measure students' listening and reading comprehension abilities in English. Researchers used the official practice ACT English and Reading exams to assess students' reading comprehension abilities as well as students' knowledge of English writing conventions and grammar. After students finished the exams, students completed survey questions that asked students to reflect on their opinions of each test's difficulty level, accuracy in measuring English ability, and usefulness as a practice test in adult ESL classrooms. Although students were in the final month of their semester long college-preparatory program, results from the standardized exams showed that few students met college readiness benchmarks on the ACT reading and English exams.

\section{Literature Review}

Depending on the program, adult English as a Second Language (ESL) programs can have different goals including workforce development training, increased community involvement, and preparation for further study at an institute of higher education such as a technical college, community college, or university (Guth, 1993). Adult ESL programs that focus on preparing students for higher education coursework use formative and summative assessments to evaluate participant's progress. Likewise, colleges and universities consider international students' 
scores on standardized exams such as the TOEFL, IELTS, and PTE as an indicator of students' English proficiency and overall college readiness. Students, themselves, benefit from having an accurate understanding of their respective level of English proficiency, academic progress, and level of college readiness (Chalhoub-Deville and Turner, 2000).

College readiness proves to be a significant topic in both K-12 and higher education research. Extant research documents the benefits of students understanding their college readiness to help in their higher education planning and pursuits (Foote et al., 2015). In the United States, both public and private universities use the ACT college admissions exam as one of their primary measures for college readiness. As Nick (2017) reports, "More than 2 million of this year's high school graduates took the ACT, accounting for an estimated 60 percent of the class. Their average composite score was 21 out of a maximum 36 on the multiple-choice test of English, math, reading and science learning. That was up from 20.8 a year before" (para. 8). Moreover, research shows that ACT scores and high school GPAs are a valid predictor of college GPAs (Huh and Huang, 2016).

South Koreans view English as necessary for achieving success. Specifically, Koreans with high levels of English language competence have increased access to prestigious universities and professional employment opportunities (Morris et al., 2018). Many educational experts consider South Korea to be an international leader in education. Indeed, South Korean students achieve some of the highest scores on worldwide competitive exams (Education Leaders: Finland and South Korea, 2013). In South Korea, students who aspire to attend institutes of higher education take the Korean College Scholastic Ability Test (CSAT), a national standardized college entrance exam created by more than 650 test-designers, content experts, and psychometricians working for the Korea Institute for Curriculum and Evaluation (KICE). In 2011, over 600,000 test-takers sat for the CSAT exam in hopes of attaining admission into Korean universities. One of the three principal sections of the test evaluates test taker's English language abilities (Lee and Winke, 2013).

Currently, a dearth of research exists on the benefits of using the CSAT as an assessment tool for English Language Learners living outside Korea. However, based on existing research of the English language needs of college students, the CSAT test could prove to be a very useful assessment for college-bound ESL students in the United States. First, in terms of the listening section of the CSAT, students must listen to a given conversation and draw conclusions using related images, sentences, or paragraphs of text. This type of questioning evaluates students' abilities to synthesize information heard orally and form connections with other sources. These aforementioned skills prove especially important in the college classroom as much of the instruction occurs in a lecture format. In fact, in a survey of college professors conducted by Johnson and Parrish (2010) that documented professors' perceptions of the fundamental academic skills needed for college success, 55.2\% of the professors participating in the study viewed the skill of synthesizing content discussed in lectures and information from textbased sources as "very or extremely important." Moreover, $78.9 \%$ of professors answered that they tested their college students on content provided during lectures and/or through audio-visual materials such as DVDs (Johnson and Parrish, 2010). Likewise, the CSAT's reading portion of the test asks students to identify details from the text, use textual evidence to draw conclusions, and evaluate the importance of given paragraphs within a larger text. Practice with these types of skills would further benefit ELL students interested in pursuing college coursework as more than half (55.2\%) of the college professors who participated in Johnson and Parrish (2010) study responded "that evaluating the value of information read is very or extremely important" (Johnson and Parrish, 2010).

\section{Methodology}

The current research project aspired to measure the English proficiency level of students in the adult ESL program at a regional state university in the Southwest. The participants of the study included adult ESL students who were pursuing coursework as part of a college- preparatory ESL program affiliated with the university. The participants included international students from South America, the Middle East, and Southeast Asia who were fulfilling their English proficiency prerequisites for admission into the university. Eight out of the nine students in the program chose to participate in the study. All of the students participating in the study had been studying English in the United States for a year or less. However, the range of years that students had studied English in their home countries varied from 1 year to 12 years.

As the study intended to evaluate students' perceptions of the relevance of the Korean College Scholastic Ability Test (CSAT) as an assessment tool for adult ESL classrooms, the researchers used the CSAT exam to evaluate participants' English language abilities in the domains of listening, grammar, and reading comprehension. A native Korean speaker translated instructions for taking the test from the original Korean to English and all test content remained in its original English format. As a second measure of participants' college readiness and as a tool for comparison, researchers administered an official practice ACT reading test to measure students' reading comprehension and an ACT English exam to assess students' grammar knowledge and understanding of writing conventions. The research team administered all exams, and students completed each test individually following each test's published guidelines. Students took one test per day on three separate days. When students finished each test, students completed a questionnaire concerning their opinions on the given test. In order to maintain confidentiality, participants received a Unique Identification Number (UIN) that only the designated research team would recognize. When completing the test, participants recorded their UIN number on the back of the test booklet. Students sat separately at different tables to ensure test confidentiality.

\section{Results}

The research team analyzed the tests upon completion and organized results into the following four categories: 1) student demographics, 2) analysis of test and survey results, 3) students' self-assessment of their performance, and 4) college readiness analysis. 


\subsection{Student Demographics}

The study noticed that the participants were diverse in country of origin, native language, gender, and age (as shown in the Figures 1, 2, 3, and 4).

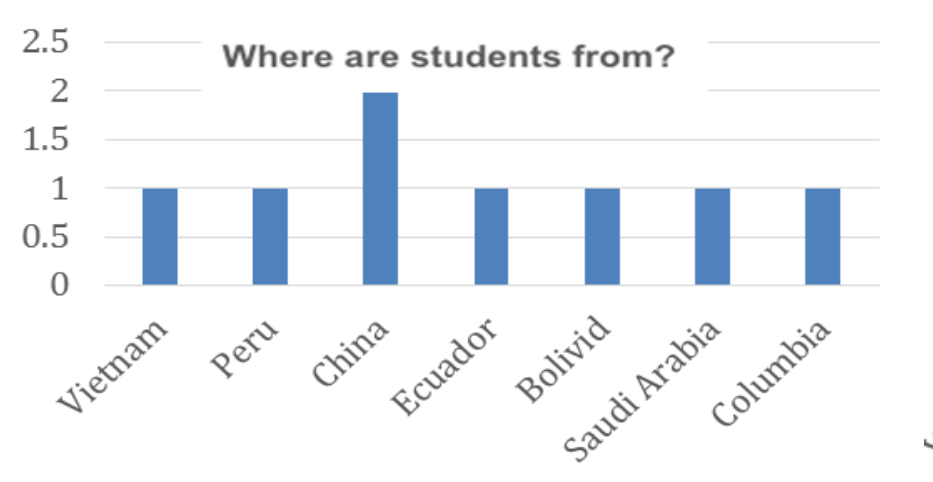

- Original Country

Figure-1. Student country of origin.

\section{Student Gender}

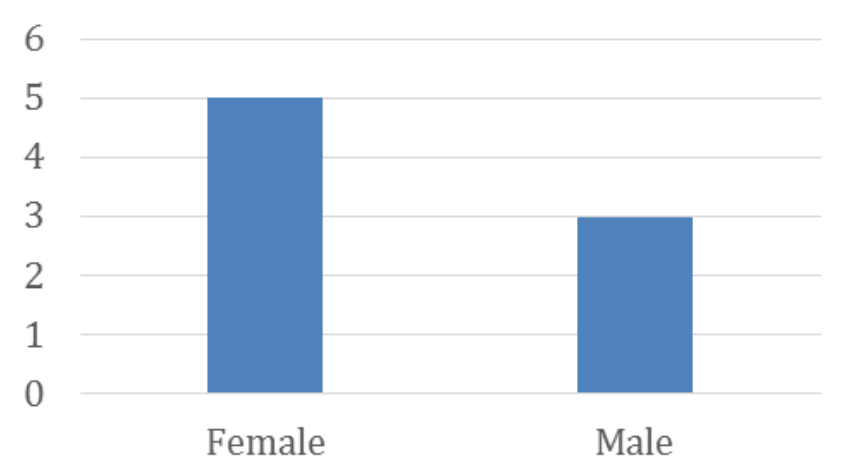

Gender

Figure-3. Student gender.

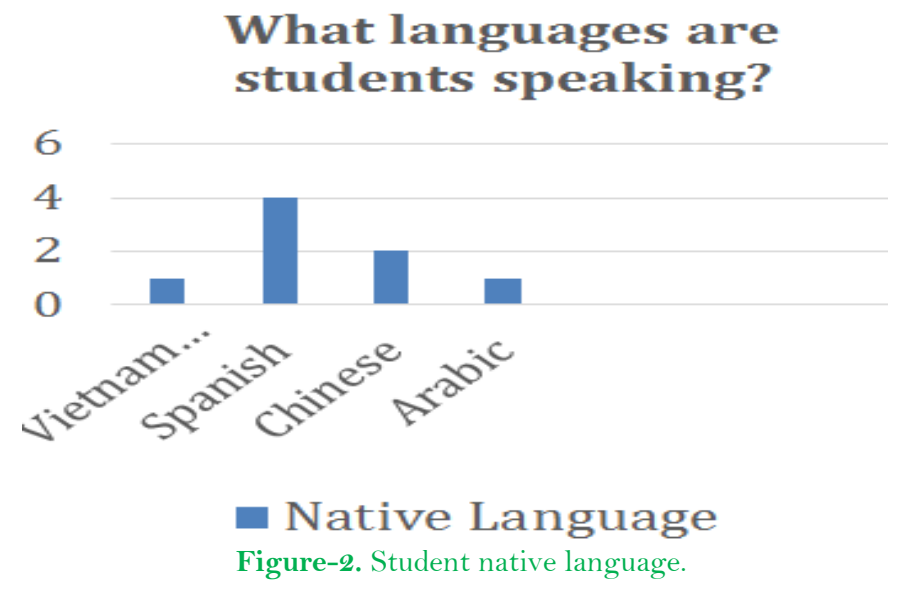

How old are students?

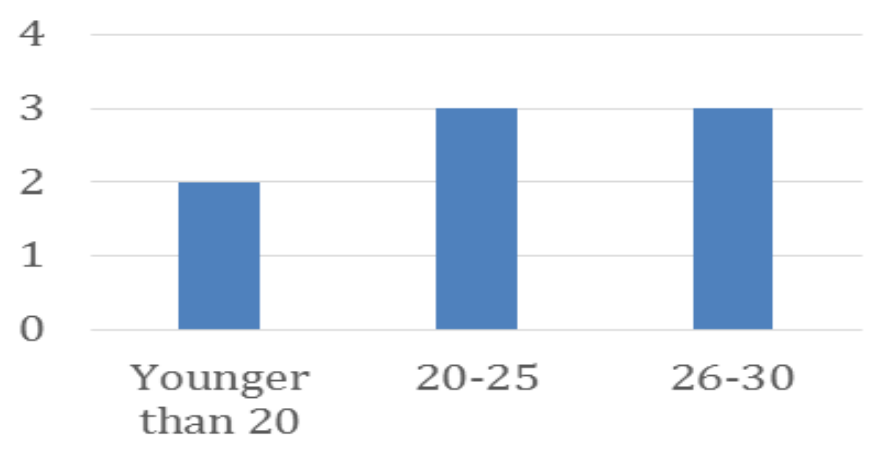

Age

Figure-4. Student age.

\subsection{Analysis of Test and Survey Results}

The research study considered the number of years participants had studied English in their home country and in the US. Interestingly, an analysis of test results showed that test results and the number of total years in which students had studied English did not appear closely related. For instance, student 6 demonstrated the highest performance on the CSAT listening and reading test, but only had studied English for 2 years in her home country. On the other hand, student 3 who had studied English for 12 years in his home country, demonstrated strengths on the reading and grammar areas, but struggled with the CSAT listening section.

\section{Years of learning English}

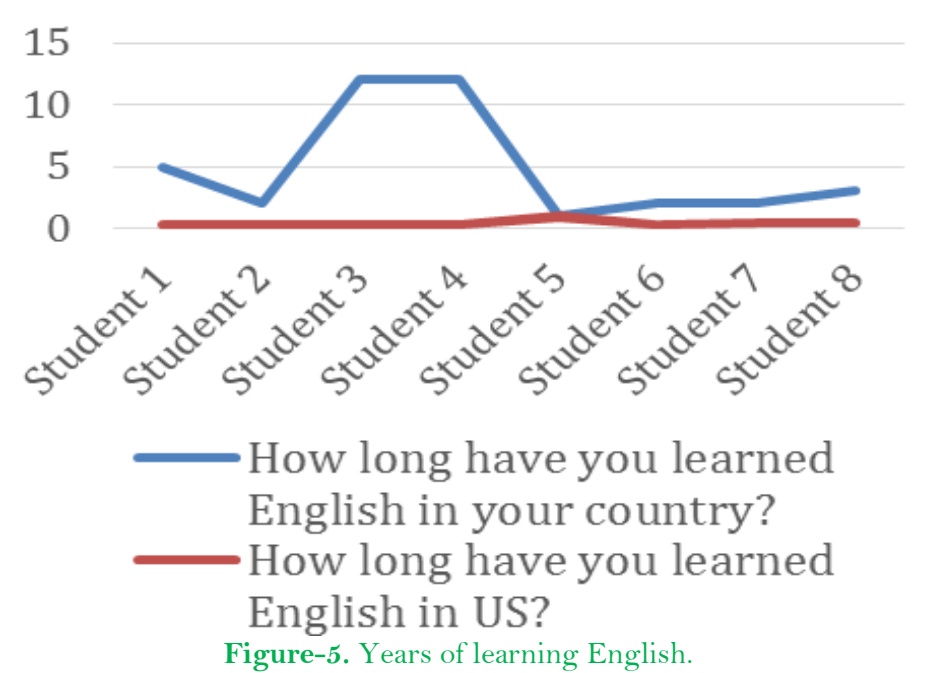

All Test Analysis

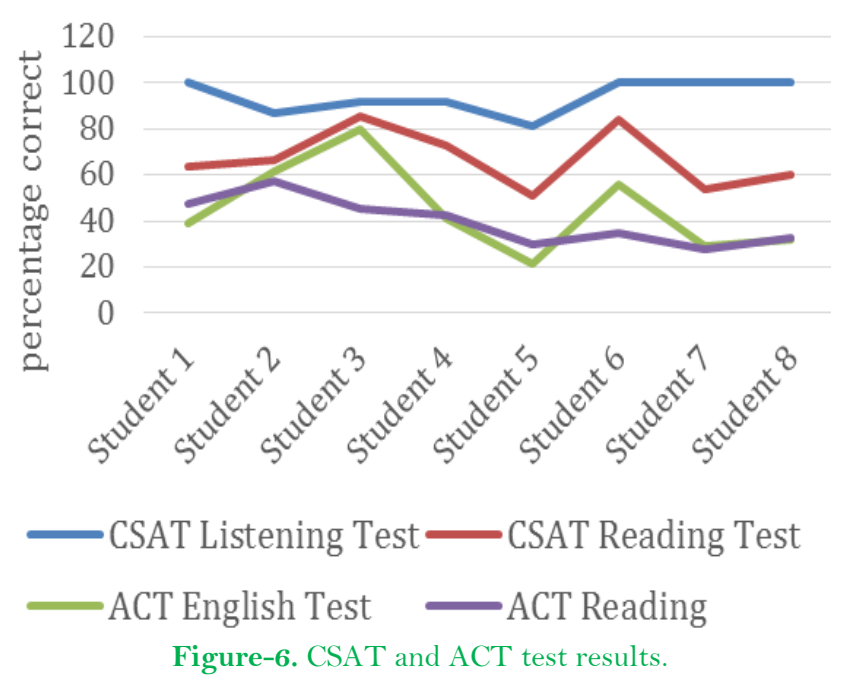

When students reflected on whether each test was an accurate measure of students' English language ability, a greater percentage of the students considered the CSAT to be an accurate measure of students' English language ability compared to both the ACT English and reading tests. All eight participants either agreed or strongly agreed that the CSAT accurately measured their English language skills. In contrast, six out of the eight participants agreed or strongly agreed that the ACT reading test was an accurate measure of students' English abilities, and five out of the eight participants agreed or strongly agreed in the accuracy of the ACT English test. 
The test was an accurate measure of my English language ability.

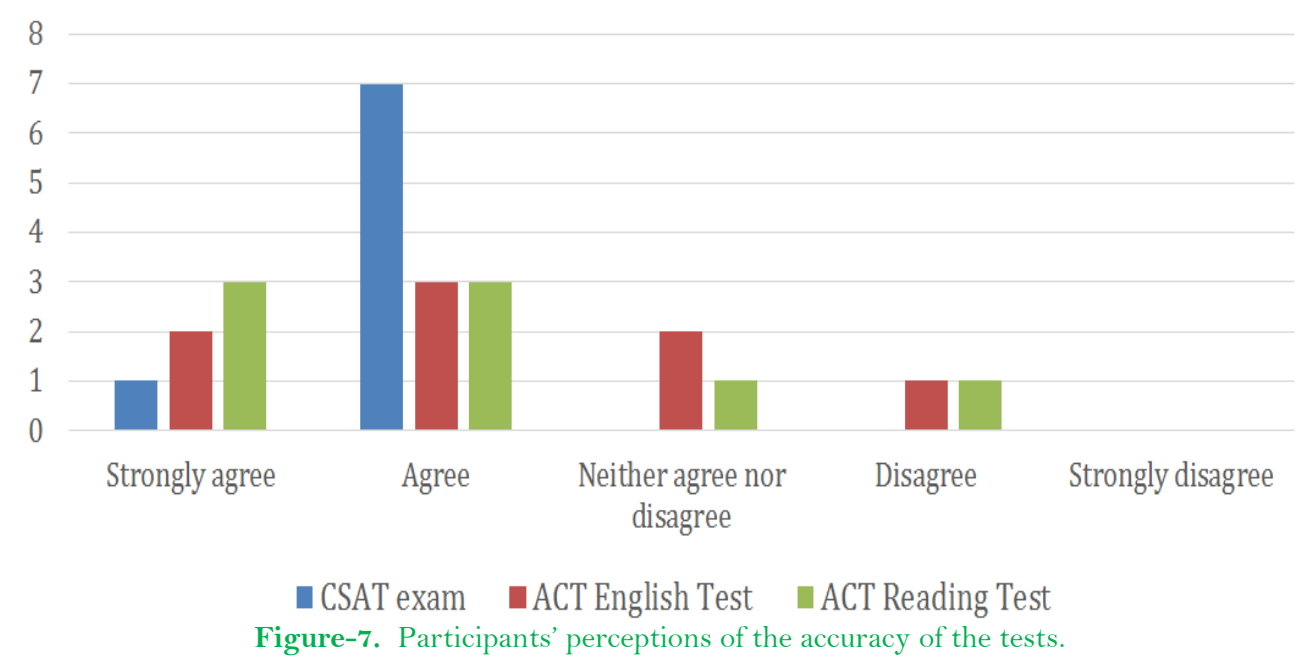

In terms of the statement "taking the test would benefit ESL students in their English learning," an overwhelming majority of students "agreed" or "strongly agreed" that taking each of the three tests would be beneficial. Specifically, all students believed taking the ACT English test would be beneficial for ESL students, while seven out of the eight students agreed that the CSAT test would be beneficial. Six out of the eight students thought that taking the ACT reading test would benefit ESL students.

Taking the test would benefit ESL students in their English learning,

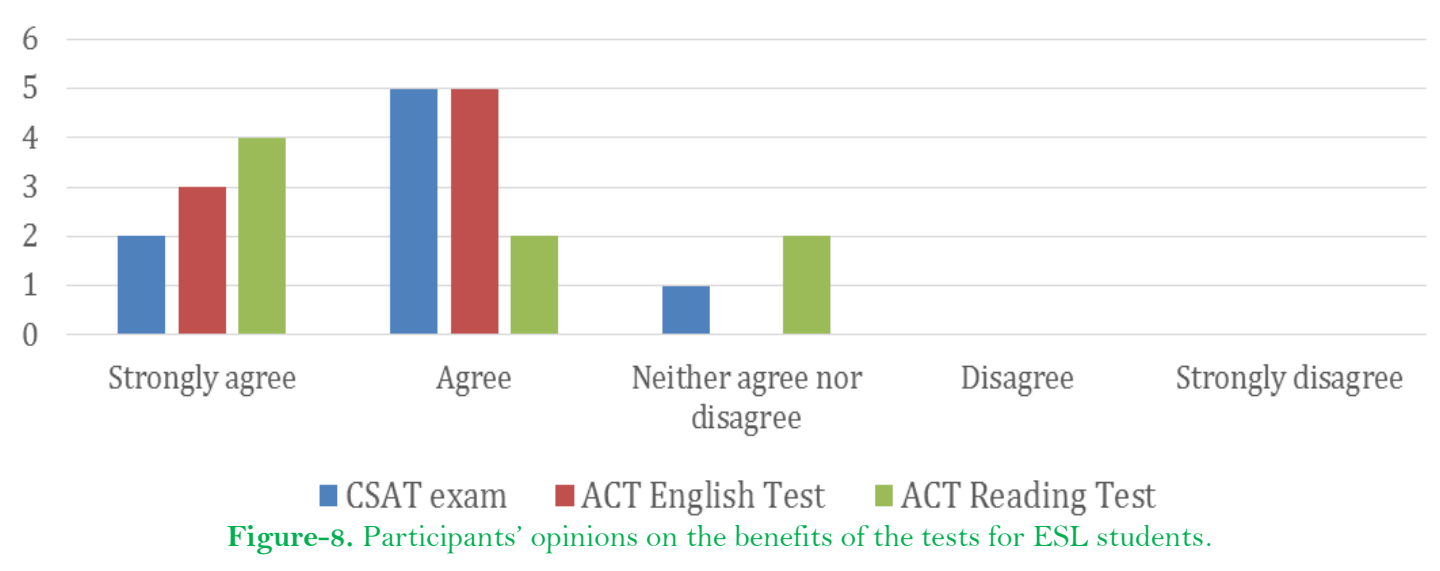

Interestingly, when students responded to the question of whether they would recommend other ESL students to take each test, students were more likely to recommend fellow ESL students to take the CSAT and the ACT reading tests and less likely to recommend the ACT English test. For both the CSAT and the ACT reading tests, seven out of the eight students agreed or strongly agreed that they would recommend for other ESL students to take the test. However, when it came to the ACT English test, only five of the eight students-a narrow majoritywould recommend that other ESL students take the test.

Concerning level of difficulty, students found the CSAT to be less difficult than the ACT English and ACT reading test. While five out of the eight students found the ACT English test to be "very difficult," and four out of the eight students found the ACT reading test to be "very difficult," no students perceived the CSAT test as "very difficult." In fact, half of the students found the CSAT to be "slightly difficult" while the remaining three students who answered the question (one student declined to respond) considered the test neither easy nor difficult.

\subsection{Students' Self-Assessment of their Performance}

Furthermore, students conducted a self-assessment on how they performed on each test. The majority of students felt they performed substantially better on the CSAT exam than the ACT tests as shown in Figure 9. However, Table 1 indicates that a clear relationship did not exist between students' self-assessment of their performance and their actual performance. For example, student 5 received the lowest score on the ACT English exam, but self-assessed that he performed very well on the test.

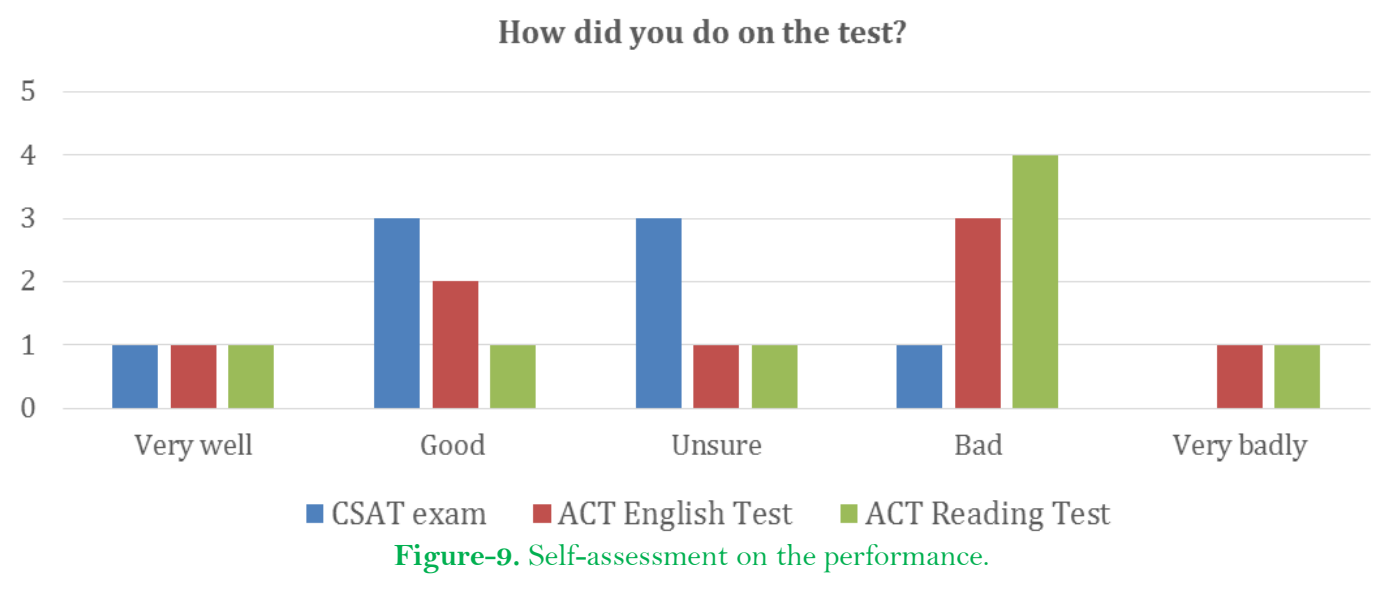


Table-1. CSAT/ACT test results and ESLI student survey responses.

\begin{tabular}{c|c|c|c|c|c|c}
\hline $\begin{array}{c}\text { Assigned } \\
\text { student } \\
\text { number }\end{array}$ & $\begin{array}{c}\text { Actual } \\
\text { test } \\
\text { score }\end{array}$ & $\begin{array}{c}\text { How easy or } \\
\text { difficult was the } \\
\text { exam? }\end{array}$ & $\begin{array}{c}\text { How do you } \\
\text { think you did } \\
\text { on the exam? }\end{array}$ & $\begin{array}{c}\text { Actual } \\
\text { test } \\
\text { score }\end{array}$ & $\begin{array}{c}\text { How easy or difficult } \\
\text { was the exam? }\end{array}$ & $\begin{array}{c}\text { How do you } \\
\text { think you did } \\
\text { on the exam? }\end{array}$ \\
\hline 001 & $77 \%$ & $\begin{array}{c}\text { Neither easy nor } \\
\text { difficult }\end{array}$ & Bad & $38.7 \%$ & Very difficult & Very badly \\
\hline 002 & $74 \%$ & Slightly difficult & Unsure & $61.3 \%$ & Slightly difficult & Good \\
\hline 003 & $88 \%$ & Slightly difficult & Good & $80 \%$ & Neither easy nor difficult & Good \\
\hline 004 & $80 \%$ & Slightly difficult & Unsure & $41.3 \%$ & Very difficult & Bad \\
\hline 005 & $62 \%$ & Slightly difficult & Very well & $21.3 \%$ & Very difficult & Very well \\
\hline 006 & $90 \%$ & $\begin{array}{c}\text { Neither easy nor } \\
\text { difficult }\end{array}$ & Good & $56 \%$ & Very difficult & Unsure \\
\hline 007 & $71 \%$ & $\begin{array}{c}\text { Neither easy nor } \\
\text { difficult }\end{array}$ & Unsure & $29.3 \%$ & Very difficult & Bad \\
\hline 008 & $75 \%$ & Slightly easy & Good & $32 \%$ & Slightly difficult & Bad \\
\hline
\end{tabular}

\subsection{College Readiness Analysis}

The study also examined the college readiness measures using the CSAT and ACT exams. Table 2 shows the rank and cutoff scores for Korean students who took the English test based on the 2018 college admissions standards in Korea. Approximately 10\% of Korean students met the top rank, while only one student in the study met this category. However, all participants met the first four ranks as shown in the last column in Table 2 . If these students applied for admission to Korean universities, one student would likely receive admission to the topranked, first-tier colleges in Korea and two students may have received admission to second-tier colleges. Students earning in the 60-70 percentile on the CSAT would also have received admission to colleges in Korea, but not at elite colleges or universities (Skycode, 2018).

Table-2. Score distribution chart

\begin{tabular}{c|c|c|c|c}
\hline Rank & $\begin{array}{c}\text { Cutoff } \\
\text { score }\end{array}$ & $\begin{array}{c}\text { Number of Korean Students } \\
\text { who met this category }\end{array}$ & $\begin{array}{c}\text { Percentage (Korean } \\
\text { Students) }\end{array}$ & $\begin{array}{c}\text { Number of ESLI Students at } \\
\text { WTAMU who met this category }\end{array}$ \\
\hline 1 & 90 & 52,983 & $10.03 \%$ & 1 \\
\hline 2 & 80 & 103,756 & $19.65 \%$ & 2 \\
\hline 3 & 70 & 134,275 & $25.43 \%$ & 1 \\
\hline 4 & 60 & 94,871 & $17.97 \%$ & $10.49 \%$ \\
\hline 5 & 50 & 55,391 & $6.74 \%$ & \\
\hline 6 & 40 & 35,576 & $4.74 \%$ & \\
\hline 7 & 30 & 25,050 & $3.49 \%$ & \\
\hline 8 & 20 & 18,441 & $1.46 \%$ & \\
\hline 9 & Below 20 & 7,721 & & \\
\hline \multicolumn{2}{l}{} \\
\hline
\end{tabular}

The ACT exam provides its own college readiness measure for each of its subject tests. For the ACT English exam, the benchmark score is 18 , while the benchmark score for the ACT Reading portion of the exam is 22 . The college readiness benchmarks are based on the average score that test takers earned that corresponded with $50 \%$ of those same test takers earning a letter grade of "B" or higher on particular college courses. On the ACT English exam, half of the students who met the college readiness benchmark would be likely to score a "B" on English Composition I. Half of the students who met the college readiness benchmark on the ACT Reading exam would be statistically likely to earn a "B" in the college liberal arts classes of psychology, sociology, political science, economics, and history (Allen and Radunzel, 2017).

Only one student met both the ACT English and Reading exams' college readiness benchmark standard, and two students met the ACT English exam's college readiness standards but not the ACT Reading's college readiness standards. This result indicates that according to the ACT college readiness benchmark, the majority of participants in the study might face difficulty in their college level coursework (see Table 3). However, it is important to note that only $60 \%$ of U.S. high school students who take the ACT English exam and $46 \%$ who take the ACT Reading exam meet college readiness benchmarks (ACT, 2019).

\begin{tabular}{c|c|c|c|c}
\hline $\begin{array}{c}\text { Assigned } \\
\text { student } \\
\text { number }\end{array}$ & $\begin{array}{c}\text { ACT English } \\
\text { test } \\
\text { (correct answers } \\
\text { out of 75 total } \\
\text { questions) }\end{array}$ & $\begin{array}{c}\text { Met College Readiness } \\
\text { Benchmark on the ACT } \\
\text { English test } \\
\text { (a minimum of 37 correct } \\
\text { answers out of 75) }\end{array}$ & $\begin{array}{c}\text { ACT Reading test } \\
\text { answer correct out of } \\
\text { 40 total questions) }\end{array}$ & $\begin{array}{c}\text { Met College Readiness } \\
\text { Benchmark on the ACT } \\
\text { Reading test (a } \\
\text { minimum of 21 correct } \\
\text { answers out of 40) }\end{array}$ \\
\hline 001 & $29(38.7 \%)$ & No & $19(47.5 \%)$ & No \\
\hline 002 & $46(61.3 \%)$ & Yes & $23(57.5 \%)$ & Yes \\
\hline 003 & $60(80 \%)$ & Yes & $18(45 \%)$ & No \\
\hline 004 & $31(41.3 \%)$ & No & $17(42.5 \%)$ & No \\
\hline 005 & $16(21.3 \%)$ & No & $12(30 \%)$ & No \\
\hline 006 & $42(56 \%)$ & Yes & $11(35 \%)$ & No \\
\hline 007 & $22(29.3 \%)$ & No & $13(32.5 \%)$ & No \\
\hline 008 & $24(32 \%)$ & No & & No \\
\hline
\end{tabular}

When the researchers analyzed the most-frequently missed questions on the CSAT test, researchers noted that most students had difficulty with the grammar related items such as appropriate word choice, parts of speech, verb tense, sentence structure, conjunctions, punctuation, possessive form, singular vs. plural tense agreement, and the 
use of adverbs. In terms of reading comprehension, students missed reading comprehension questions related to determining the main idea of a text and vocabulary questions related to selecting the most appropriate word based on the context of the passage. After an analysis of the ACT test results, frequently missed questions likewise involved questions concerning grammar related items such as punctuation, adverbs, possessive form, verb tense agreement, and conjunctions.

\section{Discussion}

This research was a pilot study to investigate adult ESL students' college readiness and perceptions of their English proficiency using three different tests: the Korean College Scholastic Ability Test (CSAT), the ACT English Test, and the ACT Reading Test.

Based on their responses, participants felt that the CSAT would be a beneficial assessment tool for future adult ESL classrooms. Since respondents considered the CSAT test to be a meaningful assessment, other adult ESL students' might also find the test useful for their college English preparation. Research shows that students' perceptions of the meaningfulness of exams affects their overall motivation and test performance. Cole et al. (2008) documented undergraduate students' perceptions of low stakes exams and students' performance on the exams. The authors found that students' perceptions of the "usefulness" and "importance" of low stakes exams affected their motivation to take the exams as well as their overall exam performance (Cole et al., 2008). Thus, the CSAT could prove to be a meaningful assessment for other English Language Learners pursuing college coursework, which would increase students' motivation and overall test performance.

Moreover, years of English study among the respondents did not necessarily correspond to performance on each of the three assessments. Thus, one could argue that "quality over quantity" could be a good maxim in English language instruction. The present findings correspond to educational research that have provided different calculations of the number of years of English instruction ELL students must receive in order to have academic English language proficiency. Academic English language proficiency proves necessary to comprehend the academic language used on standardized tests (Baker, 2011). Based on their research results from two California school districts, Hakuta et al. (2000) reported that academic English proficiency could take ELL students 4 to 7 years to learn. The authors further recommended that ESL programs follow a balanced curriculum that pays attention not only to students' English language acquisition, but also to the academic needs of each individual student. Motamedi (2015) who examined the period of time that English language learners in Washington took to become proficient in English, concluded that ELL students, who entered U.S. schools in first grade, took 3.8 years to develop their English proficiency, while students who entered in grades 2-5 took 4.3 years. Moreover, other research has found similar results to the present study in which the number of years of English instruction does not necessarily correlate with ELL students' English proficiency level. In her case study of immigrant students at a high school in Texas, Garza (2016) pointed out that educators must consider individual educational and noneducational factors when predicting the time that ELL students take to develop academic English proficiency. Garza (2016) concluded that educational factors such as the number of year's students had studied English and students' motivation for acquiring a new language had an effect on how quickly students becam proficient in English, but non-educational factors such as students' home environment, personalities, gender, and cultural/linguistic backgrounds also played a significant role in the speed in which students gained academic English proficiency.

According to the results of the present study, adult ESL students might not be accurate judges of their own performance on college readiness exams, which corresponds to existing research that has documented how college students, in general, possess misplaced overconfidence in their college readiness. As Verrell and McCabe (2015) documented, college students often incorrectly assess their level of college readiness. Specifically, college students assume they are prepared for college, yet college professors largely perceive college students as lacking fundamental college skills. Specifically, Verrell and McCabe (2015) found that $70 \%$ of college students considered themselves well prepared for college from their high school coursework, yet half of the college students surveyed also conceded that their college work had been more challenging than they had initially predicted (Verrell and McCabe, 2015). Moreover, in an earlier 2006 study by the Chronicle of Higher Education Journal by Sanoff (2006) that surveyed college professors, $37 \%$ of respondents classified their college students as lacking basic skills essential for college success. Likewise, $40 \%$ of professors participating in the study considered students deficient in their organization and planning skills as well as in students' ability to read and comprehend complex course materials (Sanoff, 2006; Verrell and McCabe, 2015).

In addition, results from the present study indicate that the majority of participants may lack college readiness skills after participating in only one semester of an ESL college-bridge program. However, it is important to note that ESL students' performance on basic skills assessments in reading and writing are not always statistically significant predictors of ESL college students' eventual academic success. Specifically, Patkowski (1991) reported that ESL students' reading and writing scores on the City University of New York's basic skills test did not have a significant statistical relationship to the students' eventual academic grade point averages (GPAs) in their college coursework (Patkowski, 1991).

On another note, adult ESL students who participated in the study missed similar types of listening, grammar, and reading questions. The students would benefit from research-proven best practices to build their abilities in each area, elaborated below.

Listening is an essential component in the process of learning a second language, but most teachers do not offer a variety of instructional activities to develop competent listening abilities (Siegel and Siegel, 2015). According to Zeng and Goh (2018) the most fundamental prerequisite to build up students' self-confidence and to motivate students to learn a new language is to promote listening skills. The authors found that a self-regulated learning approach improved second language learners' listening skills through task definition, goal setting, strategy enactment, and metacognitive adaptation. Zeng and Goh (2018) strongly recommended the use of selfdirected listening activities to assist learners to plan and prepare well for listening tasks, to monitor comprehension, and to evaluate the effectiveness of utilizing specific listening strategies. Siegel and Siegel (2015) 
investigated the use of differentiated listening instructional activities for improving L2 adult learners' listening skills. The authors suggested employing explicit listening instruction that began at the most basic level (Siegel and Siegel, 2015).

Grammar has always been an issue for students who are learning English as a second language, but, historically, second language acquisition programs have neglected explicit grammatical instruction. Pawlak (2018) introduced the Grammar Learning Strategy Inventory (GLSI) as a basis of the classification of strategies for learning grammar in a second language context. He classified the grammar learning strategy (GLS) into 4 different categories: 1) the explicit instruction of metacognitive strategies including planning, organizing, monitoring, and self-evaluation; 2) the instruction of cognitive strategies that assist the comprehension of grammar in communicative tasks; 3) teaching students affective strategies to help students face problems that might occur during the process of grammar practice; and 4) providing students with social strategies to support students' collaboration with the teacher and students' peers. Through interaction with others, second language learners may feel better about their expressive abilities. Teachers can guide these learners with appropriate cognitive and metacognitive strategies to increase affective self-confidence and to promote social interactions (Pawlak, 2018). As Gaines (2015) indicated, providing English Language Learners (ELLs) with open-ended interactions with native English speakers boosted English Language Learner's self-confidence, which proves critical for students' overall success. Benati (2017) suggested teachers offer pedagogical interventions in second language grammar instruction by changing the way instructional input is perceived and processed and by making input more noticeable to second language learners. Furthermore, teachers should encourage their students to work collaboratively to achieve a common goal by applying their knowledge of particular grammatical forms or structures (Benati, 2017).

Besides grammar, students in the study also had trouble with reading comprehension questions that required students to identify the main idea of texts. Students also experienced difficulty with questions that asked students to select the appropriate vocabulary word based on textual context. In order to develop these needed areas, research suggests utilizing structured literacy with an emphasis on direct, explicit, and systematic instruction (Motamedi, 2015; Spear-Swerling, 2018; Gentry and Ouellette, 2019). Gentry and Ouellette (2019) pointed out the gap between the scientific study of reading and actual teaching practices. The authors recommended teachers to employ the science of teaching reading by focusing on two-way, teacher-student interactions in which students and teachers held conversations concerning their interpretations of a given text. Spear-Swerling (2018) also contended that the key features of structured literacy involve the explicit, systematic, and sequential teaching of literacy at multiple levels. The explicit instruction should focus on the topics of vocabulary, sentence structure, comprehension, increased student-teacher interaction, and teacher-led corrective feedback. In terms of effective vocabulary instruction, teachers must provide students with exposure to academic English using visual contextual support, demonstrations of examples of the word vs. non-examples, and daily vocabulary practice routines (Echevarria et al., 2010). For explicit reading comprehension instruction, teachers should model to students how to determine the main idea and supporting details, model reading comprehension strategies, provide students with regular practice, and offer students frequent opportunities to discuss with their peers how they applied the particular reading strategy in a given practice activity (Au, 2006).

One limitation of the present study involved its small sample size of eight participants. Moreover, an additional limitation to the study was that data came from only one source-ESL students participating in the ESL collegebridge program at a regional university in the Southwest. The authors suggest that future research should expand on the current study through the collection of additional data from different ESL programs across various U.S. colleges and universities. These additional research efforts will help to gauge students' perceptions of their relative college readiness and the usefulness of using each of the tests to assess ESL students' college readiness. Moreover, further research will help educators in their future work to effectively advise and mentor college-bound ESL students.

The authors of this study hope that future research further expand the present study through obtaining a larger sample size and more generalizable population. Therefore, educators can more conclusively determine whether using the CSAT, ACT English, and ACT Reading tests in the adult ESL classroom as assessments yields beneficial data concerning adult ESL students' reading comprehension abilities, listening skills, English grammatical knowledge, and overall college readiness. Furthermore, additional research can provide a valuable service to students as they may use this information for their own self-monitoring of their progress in the acquisition of English. In the same vein, adult ESL professors and educational administrators can use the data to identify program successes and areas of growth. Thus, students and educators may benefit not only from learning ESL students' relative level of college readiness, but also from learning ways to support students in their continued progress in acquiring proficiency in academic English.

\section{References}

ACT, 2019. The ACT test.

Allen, J. and J. Radunzel, 2017. What are the ACT college readiness benchmarks?. ACT Research and Policy, Issue Brief. Available from https://www.act.org/content/dam/act/unsecured/documents/pdfs/R1670-college-readiness-benchmarks-2017-1 1.pdf.

$\mathrm{Au}, \mathrm{K}$., 2006. Multicultural issues and literacy achievement / Kathryn H. Au, University of Hawaii.

Bae, M. and B. Lee, 2018. Effects of text length and question type on test-takers' performance on fill-in-the-blank Items in Korean csat. English Teaching, 73(4): 149-174.Available at: https://doi.org/10.15858/engtea.73.4.201812.149.

Baker, C., 2011. Foundations of bilingual education and bilingualism. 5th Edn., Toronto, Canada: Multilingual Matters.

Benati, A., 2017. The role of input and output tasks in grammar instruction: Theoretical, empirical and pedagogical considerations. Studies in Second Language Learning and Teaching, 7(3): 377-396.Available at: https://doi.org/10.14746/ssllt.2017.7.3.2.

Bergey, R., M. Movit, A. Simpson Baird and A. Faria, 2018. Serving English language learners in higher education: Unlocking the potential. American Institutes for Research. Available from https://www.air.org/sites/default/files/downloads/report/Serving-EnglishLanguage-Learners-in-Higher-Education-2018.pdf.

Chalhoub-Deville, M. and C.E. Turner, 2000. What to look for in ESL admission tests: Cambridge certificate exams, Ielts, and toefl. System, 28(4): 523-539.Available at: https://doi.org/10.1016/s0346-251x(00)00036-1.

Cole, J.S., D.A. Bergin and T.A. Whittaker, 2008. Predicting student achievement for low stakes tests with effort and task value. Contemporary Educational Psychology, 33(4): 609-624.Available at: https://doi.org/10.1016/j.cedpsych.2007.10.002. 
Echevarria, J., M. Vogt and D. Short, 2010. Making content comprehensible for elementary English learners. The SIOP Model. Boston Ua: Pearson.

Education Leaders: Finland and South Korea, 2013. Phi Delta Kappan Magazine, 94(5): 6-7.

Foote, A., L. Schulkind and T.M. Shapiro, 2015. Missed signals: The effect of ACT college-readiness measures on post-secondary decisions. Economics of Education Review, 46: 39-51.Available at: https://doi.org/10.1016/j.econedurev.2015.02.002.

Gaines, I., 2015. Increasing confidence and English use outside the ESL/IEP classroom for lower-level learners. ORTESOL Journal, 32: 5667.

Garza, C., 2016. A case study of one public, charter school for immigrant students and English language acquisition. Lamar University Beaumont: ProQuest Dissertations Publishing.

Gentry, J.R. and G.P. Ouellette, 2019. What works and what doesn't: A critical look at current teaching practices. Brain words: How the science of reading informs teaching. Portsmouth, NH: Stenhouse Publishers.

Gjelten, T., 2015. The immigration act that inadvertently changed America. The Atlantic, 2.

Guth, G.J., 1993. Profiles of adult ESL literacy programs. TESOL Quarterly: 533-537.Available at: https://doi.org/10.2307/3587482.

Hakuta, K., Y.G. Butler and D. Witt, 2000. How long does it take English learners to attain proficiency?.The University of California Linguistic Minority Research Institute Policy Report 2000- 1.

Huh, N.R. and C. Huang, 2016. . Examining the validity of ACT composite score and high school grade point average for predicting firstyear college GPA of special-tested students. ACT Research Report Series.

Johnson, K. and B. Parrish, 2010. Aligning instructional practices to meet the academic needs of adult ESL students. TESOL Quarterly, 44(3): 618-628.Available at: https://doi.org/10.5054/tq.2010.230742_2.

Kim, K., P. Green, E. Frankenberg, G. LeTendre, R. Shouse and E. Yoder, 2012. The effectiveness of school type on atudents' academic achievement: Focusing on private high school of South Korea, ProQuest Dissertations and Theses.

Know, S., 2019. Foreign tech workers are turning to Canada as US immigration becomes more difficult. Available from https://www.knowsomething.us/article/foreign-tech-workers-are-turning-to-canada-as-us-immigration-becomes-more-difficult/.

Lee, H. and P. Winke, 2013. The differences among three-, four-, and five-option-item formats in the context of a high-stakes Englishlanguage listening test. Language Testing, 30(1): 99-123.Available at: https://doi.org/10.1177/0265532212451235.

Lee, K.S., 2014. The politics of teaching English in South Korean schools: Language ideologies and language policy.

Leiber, N., 2019. Foreign students sour on America, jeopardizing a $\$ 39$ billion industry. Bloomberg Education. Available from https://www.bloomberg.com/news/articles/2019-01-17/foreign-students-are-a-39-billion-industry-trump-is-scaring-them-off.

Morris, A., M. Lafontaine, F. Pichette and L. De Serres, 2018. Affective variables, parental involvement and competence among South Korean high school learners of English. Studies in Second Language Learning and Teaching, 3(1): 13-45.Available at: https://doi.org/10.14746/ssllt.2013.3.1.2.

Motamedi, J.G., 2015. Time to reclassification: How long does it take English learner students in Washington road map districts to develop English proficiency?. National Center for Education Evaluation and Regional Assistance: US Department of Education. Available from https://files.eric.ed.gov/fulltext/ED558159.pdf.

National Center for Education Statistics, 2019. English language learners in public schools. Available from https://nces.ed.gov/programs/coe/indicator_cgf.asp.

Nick, A., 2017. We didn't know it was this bad: New ACT scores show huge achievement gaps. Washington: Post.

Patkowski, M.S., 1991. Basic skills tests and academic success of ESL college students.TESOL Quarterly, 25(4): 735-738.Available at: https://doi.org/10.2307/3587096.

Pawlak, M., 2018. Grammar learning strategy inventory (glsi): Another look. Studies in Second Language Learning and Teaching, 8(2): 351379.Available at: https://doi.org/10.14746/ssllt.2018.8.2.8.

Redden, E., 2018. New international enrollments decline again. Inside Higher Ed. Available from https://www.insidehighered.com/news/2018/11/13/new-international-student-enrollments-continue-decline-us-universities.

Sanoff, A.P., 2006. A perception gap over students' preparation. Chronicle of Higher Education, 52(27): B9-B14.

Siegel, J. and A. Siegel, 2015. Getting to the bottom of L2 listening instruction: Making a case for bottom-up activities. Studies in Second Language Learning and Teaching, 5(4): 637-662.

Skycode, 2018. Korea college entrance exam analysis.

Spear-Swerling, L., 2018. Structured literacy and typical literacy practices: Understanding differences to create instructional opportunities. SAGE Journals, 51(3): 201-211.Available at: https://doi.org/10.1177/0040059917750160.

Verrell, P.A. and N.R. McCabe, 2015. In their own words: Using self-assessments of college readiness to develop strategies for self-regulated learning. College Teaching, 63(4): 162-170.Available at: https://doi.org/10.1080/87567555.2015.1053046.

Zeng, Y. and C.C. Goh, 2018. A self-regulated learning approach to extensive listening and its impact on listening achievement and metacognitive awareness. Studies in Second Language Learning and Teaching, 8(2): 193-218.Available at: https://doi.org/10.14746/ssllt.2018.8.2.2.

Zong, J. and J. Batalova, 2018. International students in the United States. Migration Policy Institute. 